\title{
Проблемы разрешения споров \\ во внешнеэкономических отношениях \\ Республики Узбекистан
}

Самарходжаев Б.Б.*

В Республике Узбекистан формируется собственная система управления внешнеэкономическими отношениями с действенным механизмом экономических, политических, научных, правовых мер организации их регулирования, цель которых - интегрирование Узбекистана в мировую экономическую систему на принципах равноправия и взаимной выгоды.

Развитие международных связей немыслимо без создания внешнеэкономической инфраструктуры. При этом необходимо учитывать одну из приоритетных задач - либерализацию экономической деятельности при сокращении административных ограничений и замене их общепризнанными международными нормами и правилами, рыночными инструментами регулирования.

Одной из предпосылок успешного развития внешнеэкономических отношений для всех государств является обеспечение для партнеров возможности судебной защиты своих прав и интересов.

В настоящее время споры экономического характера между национальными и иностранными субъектами разрешаются хозяйственными судами Республики Узбекистан или посредством международного коммерческого арбитража в соответствии с положениями международных договоров.

Стороны, вовлеченные в спор, по взаимной договоренности могут определить орган, рассматривающий такой спор, а также страну арбитражного судопроизводства.

Иностранные организации, международные организации и осуществляющие предпринимательскую деятельность иностранные граждане, лица без гражданства (далее - иностранные лица) имеют право обращаться в хозяйственные суды Республики Узбекистан для защиты своих нарушенных или оспариваемых прав и охраняемых законом интересов.

- Самарходжаев Батыр Билялович - д.ю.н., декан юридического факультета Национального университета Узбекистана. 
Иностранные лица пользуются процессуальными правами и имеют процессуальные обязанности наравне с организациями и гражданами Республики Узбекистан. Судопроизводство по делам, в которых участвуют иностранные лица, осуществляется в соответствии с Хозяйственным процессуальным кодексом Республики Узбекистан (ХПК РУ

Рассмотрение споров в судебном порядке может быть идеальным решением в том случае, если стороны имеют одну и ту же национальную принадлежность и понимают правовой режим и судебную систему, на рассмотрение которой представлен спор. Рассмотрение в судебном порядке предусматривает сбор свидетельских показаний и опрос свидетелей при рассмотрении дела. Однако в том случае, когда в инвестиционный спор вовлечена международная организация, могут использоваться альтернативные механизмы урегулирования споров'. В тех случаях, когда спор возникает в международном контексте, чаша весов, безусловно, склоняется в пользу его разбирательства в международном коммерческом арбитраже (третейском суде), обладающем рядом достоинств: относительная быстрота разбирательства, добровольность передачи спора на арбитраж, свободный выбор сторонами арбитров и места рассмотрения спора, выбор языка рассмотрения дела, высокая компетентность арбитров, конфиденциальность рассмотрения споров, относительная по сравнению с судебным разбирательством дешевизна разбирательства, простота исполнения решений.

Международный коммерческий арбитраж - это негосударственный орган, который формируется из лиц, избираемых сторонами или назначаемых в соответствии с порядком, согласованным ими либо установленным законом.

Международный коммерческий арбитраж разрешает споры, возникаюшие из гражданско-правовых отношений, связанных с экономическим и научно-техническим сотрудничеством. Субъекты такого рода споров - физические и юридические лица различных стран. В некоторых случаях стороной спора, который разрешается органами международного коммерческого арбитража, может быть государство. Сторонами таких споров являются, скажем, иностранный инвестор государства-участника и государство, которое подписало соглашение о защите иностранных капиталовложений, в том числе Республика Узбекистан.

\footnotetext{
' См.: Книпер Р., Асьянов Ш., Убайдуллаев 3. Международный арбитражный суд (нормативные акты, комментарии). Ташкент, 1999. С. 99.
} 
Такие споры могут касаться, в частности, размеров компенсации, связанной с проведенной национализацией, реквизицией и т.п.

Международный коммерческий арбитраж следует отличать от межгосударственного арбитража, который является одним из средств мирного разрешения межгосударственных споров согласно ст. 33 Устава ООН. Органы межгосударственного арбитража разрешают споры, возникающие из международных публично-правовых отношений межвластного характера. Субъектами такого рода отношений, как правило, являются государства. Избранные сторонами арбитры разрешают подобные споры, применяя: а) международные договоры, которые устанавливают нормы, определенно признанные спорящими сторонами; б) международный обычай как доказательство всеобщей практики, признанной в качестве нормы международного права; в) общие принципы права; г) судебные решения и доктрину в качестве вспомогательного средства для толкования правовых норм.

Международный коммерческий арбитраж, конечно же, отличается от хозяйственных судов, которые действуют в соответствии с ХПК РУЗ Хотя такие суды также разрешают экономические споры, их главное отличие состоит в том, что это органы государственные. Для них характерны некоторые особенности. Согласно ХПК РУз стороны обязаны разрешать свои споры в хозяйственных судах. Отказ от права на обращение в суд недействителен. Стороны не участвуют в формировании состава судей. Рассмотрение дел является гласным.

Для того чтобы разрешить спор в органах международного коммерческого арбитража, стороны должны заключить арбитражное соглашение (компромисс) относительно уже возникшего спора или споров, которые могут возникнуть между ними в будушем. Такое соглашение, включенное в контракт при его заключении, называется арбитражной оговоркой. Следовательно, особенность органов международного коммерческого арбитража состоит в том, что стороны обращаются к ним добровольно в силу заключенного арбитражного соглашения. Иными словами, по арбитражному соглашению возникает компетенция международного коммерческого арбитража, которое имеет и другое правовое последствие: исключение юрисдикции судов общей компетенции и хозяйственных судов ${ }^{2}$.

2 См.: Международное частное право: Учебник для вузов / Под ред. д.ю.н. Н.И. Марышевой. М.: Юридическая фирма «КОНТРАКТ», «ИНФРА-М», 2000. С. 495. 
Согласно Нью-Йоркской конвенции о признании и приведении в исполнение иностранных арбитражных решений от 10 июня 1958 года ${ }^{3}$ (далее - Нью-Йоркская конвенция ООН 1958 года) «письменное соглашение» включает арбитражную оговорку в договоре или арбитражное соглашение, подписанное сторонами либо содержащееся в обмене письмами или телеграммами.

Арбитражное соглашение (англ. arbitration agreement) заключается в письменной форме - стороны не вправе отступать от этого условия.

Вместе с тем хотелось бы высказаться об этом и об исключении юрисдикции хозяйственных судов при наличии арбитражной оговорки отдельно. Пункт 2 статьи 88 ХПК РУз указывает на правовые последствия наличия арбитражной оговорки в соглашении между сторонами: хозяйственный суд оставляет иск без рассмотрения, если «имеется соглашение лиц, участвующих в деле, о передаче данного спора на разрешение третейского суда и возможность обращения к третейскому суду не утрачена и если ответчик, возражающий против рассмотрения дела в хозяйственном суде, не позднее своего первого заявления по существу спора заявит ходатайство о передаче спора на разрешение третейского суда».

Итак, арбитражная оговорка не учитывается хозяйственными судами, если истец обратился в хозяйственный суд и тем самым отказался or третейского разбирательства, а ответчик до рассмотрения спора по существу не заявил ходатайства о передаче дела в третейский суд, то есть не выразил своего возражения.

В практике хозяйственные суды не учитывают арбитражную оговорку и в том случае, если стороны не указали конкретный третейский суд. Арбитражная оговорка при этом считается отсутствующей ${ }^{4}$.

Арбитражное соглашение считается заключенным в письменной форме, если содержится в документе, подписанном сторонами, или заключено путем обмена письмами, сообщениями по телетайпу, телеграфу или с использованием иных средств электросвязи, которые обеспечивают фиксацию такого соглашения. Арбитражное соглашение может быть заключено также путем обмена исковым заявлением и отзывом на иск, в которых одна из сторон утверждает о наличии арбитражного соглашения, а другая против этого не возражает.

${ }^{3}$ Юридическая информационная система ПРАВО. Международное право. Арбитраж. Версия от 14.07.04.

${ }^{4}$ Арбитражное право Узбекистана. Вопросы санации и банкротства предприятий. 2000. № 4. C. 18. 
Поскольку исполнительное производство неизбежно проистекает из государственной монополии власти, в данный процесс необходимо включение какой-либо государственной структуры. Частные арбитражные судьи или частные арбитражные суды ни при каких обстоятельствах не могут осуществить исполнительное производство без участия государственных судов.

В республике порядок признания и исполнения решений международных коммерческих арбитражей регулируется нормами Нью-Йоркской конвенции ООН 1958 года. Вопрос о принудительном исполнении решения суда иностранного государства рассматривается по ходатайству истца соответствующими судами Узбекистана по месту нахождения должника, а если он не проживает в республике или его местонахождение неизвестно, то по месту нахождения его имущества.

Государственные суды обязаны по закону осуществлять признание упомянутых решений и объявлять их подлежащими исполнению, и только при наличии совершенно определенных предпосылок (статья 5 Нью-Йоркской конвенции ООН 1958 года) им должна быть дана возможность отказывать в признании и исполнении.

Преимущества альтернативного по отношению к государственным судам арбитражного решения споров общепризнанны, особенно в области международных экономических связей, когда одна из сторон не решается довериться судопроизводству другой страны. Это может быть связано с языковым барьером, с чуждыми правовыми традициями и неверием в беспристрастность суда. В подобных случаях со временем почти во всем мире стала признаваться возможность созыва арбитражных судов на основе волеизъявления частных лиц.

Основным элементом международного арбитражного процесса является именно его международный характер. Поэтому лучше всего следовать модельному закону ЮНСИТРАЛ, как это уже признали многие страны, в частности Германия, Россия, Канада, Австралия и др.

Международное арбитражное разбирательство, как правило, приводит к экономии как времени, так и средств, обеспечивая при этом гибкость, простоту и наличие технической экспертизы. Неформальные правила международного арбитража известны обеим сторонам, в отличие от национального законодательства, которое может быть известно лишь одной стороне. Международный арбитраж позволяет обеспечить сохранение тайны и конфиденциальности в том случае, если стороны требуют этого. Международный арбитраж не обязательно 
приводит к ухудшению отношений между сторонами, как это зачастую происходит в случае судебного разбирательства.

В международной практике известны два вида третейских судов: так называемые изолированные и постоянно действующие. Изолированный третейский суд создается сторонами специально для рассмотрения конкретного спора. Стороны сами определяют порядок создания третейского суда и правила рассмотрения в нем дела. После вынесения решения по делу такой суд прекращает свое существование. $\mathrm{OH}$ получил также название третейского суда ad hoc (буквально - «для этого", т.е. для рассмотрения данного дела).

Характерным для постоянно действующих арбитражей является то, что каждый из них имеет положение (или устав), свои правила арбитражного производства, список арбитров, из которых стороны выбирают арбитров.

В мире функционирует более 400 институционных коммерческих арбитражей. В одних только США существует национальный список арбитров, включающий более 55 тысяч специалистов в различных отраслях права или в области предпринимательской деятельности ${ }^{5}$.

Представляется, что функционирование международного коммерческого арбитража в Республике Узбекистан будет способствовать развитию ее внешнеэкономических отношений.

Здесь также следует учесть то обстоятельство, что количество дел, рассматриваемых в хозяйственных судах республики, увеличивается с каждым годом. Это положительный фактор, и он связан с активизацией предпринимательской деятельности, быстрым увеличением круга ее участников. Возрастание нагрузки на судей приводит к уменьшению времени, отводимого на каждое дело, в связи с чем все труднее становится обеспечивать качество рассмотрения дел. Поэтому со всей остротой в республике встал вопрос о создании альтернативных государственному суду органов - международных коммерческих арбитражей.

Для того чтобы обеспечить в арбитражном процессе объективное отношение к иностранному партнеру, в данной стране должны быть созданы предпосылки, заключающиеся в принятии законов об арбитражных судах и необходимости участия в Нью-Йоркской конвенции о признании и исполнении арбитражных решений.

В Узбекистане на данный момент решение этого вопроса половинчатое: Постановлением Олий Мажлиса Республики Узбекистан

${ }^{5}$ Материалы Министерства юстиция Республики Узбекистан. 
от 22 декабря 1995 года республика присоединилась к Нью-Йоркской конвенции о признании и приведении в исполнение иностранных арбитражных решений 1958 года ${ }^{6}$. Но в республике отсутствует законодательство, регулирующее деятельность международного коммерческого арбитража. В связи с этим применение Конвенции осуществляется на основе односторонних решений. Так, например, 19 января 2000 года Ташкентским городским судом было признано решение Международного арбитражного суда при Ливерпульской хлопковой ассоциации о взыскании с ГАВК «Узмарказимпекс» 790050.22 долл. США, а 13 июня 2000 года - решение Международного коммерческого суда при Торгово-промышленной палате Российской Федерации о взыскании с ТПО «Узирстройконструкция» 61414.97 долл. США.

Между тем в 1998 году в споре по делу об импорте сливочного масла в Узбекистан с немецкой компанией «Еврохандельс Гмбх» немецкий суд отказал в признании решения узбекского суда на территории Германии вследствие отсутствия договора о правовой помоши и взаимности признания подобных решений между странами и неприменимости Нью-Йоркской конвенции к данному спору. Указанная ситуация не возникла бы, если бы спор был разрешен международным коммерческим арбитражем Узбекистана, который в настояшее время не создан $^{7}$. На наш взгляд, функционирование международного коммерческого арбитража в республике при складывающихся обстоятельствах в большей мере отвечает интересам национальных субъектов - ведь решения международного коммерческого арбитража являются обязательными для исполнения более чем в 120 странах - участницах НьюЙоркской конвенции ООН 1958 года.

Суды по экономическим спорам чаще всего создаются объединениями предпринимателей. В Европе наибольшим авторитетом пользуются арбитражные суды при Международной торговой палате в Париже, Арбитражный институт Торговой палаты в Стокгольме, арбитражные суды в Лондоне и Цюрихе ${ }^{8}$. Широко известен арбитраж Американской Арбитражной Ассоциации. При Торгово-промышленной палате Российской Федерации сушествуют два постоянно действующих органа международного коммерческого арбитража. Это - Меж-

\footnotetext{
${ }^{6}$ Юридическая информационная система ПРАВО. Международное право. Арбитраж. Версия от 01.07.02.

' Материалы Министерства юстиции Республики Узбекистан.

${ }^{8}$ Богуславский М.М. Международное частное право: Учебник. М.: Юристь, 2000. C. 388 .
} 
дународный коммерческий арбитражный суд (первоначальное название - Внешнеторговая арбитражная комиссия (ВТАК)) и Морская арбитражная комиссия. В Украине существует Морская арбитражная комиссия при Торгово-промышленной палате Украины. Кроме органов международного коммерческого арбитража общей компетенции существуют и специализированные органы, например Арбитражный суд при Гдыньской федерации по торговле шерстью (1968 г.).

Изложенное обусловливает необходимость создания нормативноправовой базы деятельности международного коммерческого арбитража на территории Республики Узбекистан.

Представляется, что создание правовой базы и организация Международного коммерческого арбитража в Узбекистане будут делом чести республиканской Палаты товаропроизводителей и предпринимателей. 